\title{
Data report: late Miocene to early Pliocene coccolithophore and foraminiferal preservation at Site U1338 from scanning electron microscopy
}

\author{
Anna Joy Drury, ${ }^{2,3}$ Geoffrey P. Lee, ${ }^{2,4}$ Gillian M. Pennock, ${ }^{5}$ and Cédric M. John ${ }^{2}$
}

\section{Chapter contents}

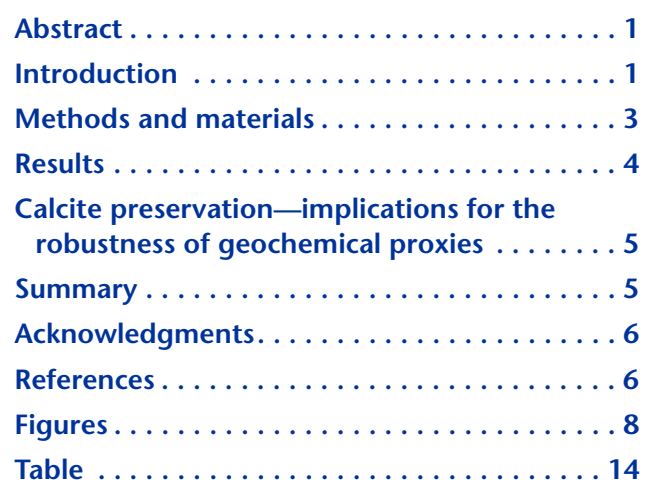

1Drury, A.J., Lee, G.P., Pennock, G.M., and John, C.M., 2014. Data report: late Miocene to early Pliocene coccolithophore and foraminiferal preservation at Site U1338 from scanning electron microscopy. In Pälike, H., Lyle, M., Nishi, H., Raffi,

I., Gamage, K., Klaus, A., and the Expedition 320/ 321 Scientists, Proc. IODP, 320/321: Tokyo (Integrated Ocean Drilling Program Management International, Inc.).

doi:10.2204/iodp.proc.320321.218.2014

${ }^{2}$ Department of Earth Science and Engineering, Imperial College London, SW7 2BP, United Kingdom.

${ }^{3}$ Present address: MARUM-Center for Marine Environmental Sciences, University of Bremen, Leobener Strasse, DE-28359 Bremen, Germany. ajdrury@marum.de

${ }^{4}$ Present address: School of Environmental Sciences, University of East Anglia, Norwich Research Park, Norwich, NR4 7T], United Kingdom.

${ }^{5}$ Department of Earth Sciences, Utrecht University, 3584 CD Utrecht, The Netherlands.

\section{Abstract}

The late Miocene to early Pliocene carbonate-rich sediments recovered at Integrated Ocean Drilling Program (IODP) Site U1338 during the Expedition 320/321 Pacific Equatorial Age Transect (PEAT) program contain abundant calcareous nanno- and microfossils. Geochemical proxies from benthic and planktonic foraminiferal and coccolithophore calcite could be very useful at this location; however, good preservation of the calcite is crucial for the proxies to be robust. Here, we evaluate the preservation of specific benthic and planktonic foraminifer species and coccolithophores in fine fraction sediment at Site U1338 using backscattered electron (topography mode) scanning electron microscopy (BSE-TOPO SEM). Both investigated foraminiferal species, Cibicidoides mundulus and Globigerinoides sacculifer, have undergone some alteration. The C. mundulus show minor evidence for dissolution, and only some specimens show evidence of overgrowth. The Gs. sacculifer show definite signs of alteration and exhibit variable preservation, ranging from fair to poor; some specimens show minor overgrowth and internal recrystallization but retain original features such as pores, spine pits, and internal testwall growth structure, whereas in other specimens the recrystallization and overgrowth disguise many of the original features. Secondary electron and BSE-TOPO SEM images show that coccolith calcite preservation is moderate or moderate to poor. Slight to moderate etching has removed central heterococcolith features, and a small amount of secondary overgrowth is also visible. Energy dispersive spectroscopy analyses indicate that the main sedimentary components of the fine fraction sediment are biogenic $\mathrm{CaCO}_{3}$ and $\mathrm{SiO}_{2}$, with some marine barite. Based on the investigations in this data report, geochemical analyses on benthic foraminifers are unlikely to be affected by preservation, although geochemical analyses on the planktonic foraminifers should be treated cautiously because of the fair to poor and highly variable preservation.

\section{Introduction}

The eastern equatorial region of the Pacific Ocean is an important component of the global climate system and is crucial for understanding climate evolution (Lyle et al., 2008). The Integrated Ocean Drilling Program (IODP) Expedition 320/321 "Pacific 
Equatorial Age Transect" (PEAT) program, drilled using the R/V JOIDES Resolution, aimed to work toward continuous high-resolution composite records of environmental change in the equatorial region between $56 \mathrm{Ma}$ and the present (Lyle et al., 2010) with the top part of Site U1338 aiming at recovering late Miocene to early Pliocene sediments (Fig. F1) (see the "Expedition 320/321 summary" [Pälike et al., 2010]). The recovered sediments are carbonate rich with abundant coccolithophores and foraminifers (see the "Site U1338" chapter [Expedition 320/321 Scientists, 2010]), which all constitute excellent archives for various geochemical proxies. However, in order to make robust inferences based on geochemical records from these calcareous fossils, good preservation of the foraminiferal and coccolithophore calcite is essential. Here, we evaluate the preservation of specific benthic and planktonic foraminifer species and coccolithophores in fine fraction sediment at Site U1338 $\left(2^{\circ} 30.469^{\prime} \mathrm{N}, 117^{\circ} 58.178^{\prime} \mathrm{W} ; 4200 \mathrm{~m}\right.$ water depth).

For geochemical applications using foraminiferal calcite, it is crucial that the calcite test is well preserved. Pristine benthic and planktonic foraminifer tests consist of calcitic microgranules ( $0.1 \mu \mathrm{m}$ diameter) that are laterally fused (Pearson and Burgess, 2008; Sexton and Wilson, 2009). The outer and inner test walls of well-preserved foraminifers are smooth on a submicrometer scale, and cross sections of the test walls have a pervasive microgranular structure (Sexton et al., 2006). The average chemical composition of the tests can be affected by later recrystallization or overgrowth with calcite that was precipitated from a secondary water mass with a different temperature and chemical composition than the water mass in which the foraminifers lived (Pearson et al., 2001; Sexton et al., 2006). Dissolution can also remove primary calcite, thereby altering the average chemical composition of the foraminifer test (Edgar et al., 2013).

Planktonic foraminifer test preservation has been described as gradationally varying between pristine "glassy" and less well preserved "frosty" preservation (Sexton et al., 2006). Glassy planktonic foraminifers are generally found in clay-rich sediments, where permeability is lower, thereby minimizing the interaction between pore waters and the primary calcite and reducing the chance of recrystallization (Pearson et al., 2001). The glassy specimens, which appear translucent under a reflected light microscope (RLM), retain their smooth test walls and the original microstructure (Sexton et al., 2006). Frosty planktonic foraminifers appear opaque when viewed under RLM and are often recovered from biogenic oozes and chalky deep-sea deposits (Pearson and
Burgess, 2008). With increasing opaqueness, frosty specimens frequently show increasing overgrowth on the interior and exterior test walls, and the test walls show widespread recrystallization of the microgranular calcite into large inorganic calcite crystals (Pearson and Burgess, 2008; Sexton et al., 2006). Widespread recrystallization and dissolution also causes the foraminifer to become mechanically weaker (Pearson and Burgess, 2008), thereby increasing the chance of fragmentation during deposition or sample processing. In addition to diagenetic alteration of the primary foraminiferal calcite, a further concern is when planktonic foraminifer test chambers contain calcite "infilling" of a different origin, such as coccolithophore calcite (Sexton et al., 2006).

As planktonic foraminifers undergo diagenetic alteration on the seafloor, recrystallization and overgrowth with inorganic calcite causes an increase in the $\delta^{18} \mathrm{O}$ values of the foraminiferal calcite (Pearson et al., 2001). If used for temperature reconstructions, recrystallized frosty planktonic foraminiferal calcite $\delta^{18} \mathrm{O}$ should provide lower temperature estimates than pristine glassy planktonic foraminiferal calcite $\delta^{18} \mathrm{O}$ (Sexton et al., 2006). No significant offset was observed between glassy and frosty $\delta^{13} \mathrm{C}$ values (Sexton et al., 2006).

Benthic foraminifers are considered less receptive to diagenetic processes such as dissolution, recrystallization, and overgrowth (Edgar et al., 2013; Sexton and Wilson, 2009). This is predominantly because benthic foraminiferal tests are generally more heavily calcified than those of planktonic foraminifers, and are therefore thought to be more resistant to both dissolution and recrystallization (Sexton and Wilson, 2009). However, recent high-resolution scanning electron microscopy (SEM) studies of benthic foraminifers have shown that the benthic species show similar levels of recrystallization at micrometer and submicrometer scale as previously found in planktonic species (Edgar et al., 2013; Sexton and Wilson, 2009). In addition, badly preserved samples show evidence of overgrowth with large inorganic calcite crystals on the internal and sometimes external test walls (Sexton and Wilson, 2009). Distinguishing the degree of internal recrystallization on the basis of external test wall preservation alone is problematic, as Edgar et al. (2013) showed that the preservation of the microgranular structure was variable between various frosty specimens, even when the outer test microstructure of the different specimens was similar. Despite similar levels of submicrometer recrystallization occurring in benthic and planktonic foraminifers, diagenetic alteration does not seem to create any offset in benthic fora- 
minifer $\delta^{18} \mathrm{O}$ and $\delta^{13} \mathrm{C}$ values compared to $\delta^{18} \mathrm{O}$ and $\delta^{13} \mathrm{C}$ from pristine specimens (Edgar et al., 2013; Sexton and Wilson, 2009). Edgar et al. (2013) suggest that the absence of an offset is related to recrystallization of the benthic foraminiferal calcite, most likely occurring in pore waters of similar temperature and chemical composition to the bottom waters where the original benthic foraminiferal calcite precipitated.

Coccolith calcite is generally preferentially preserved compared to planktonic foraminiferal calcite, as coccolith calcite is less receptive to dissolution and recrystallization (Bown and Dunkley Jones, 2012; Schmidt et al., 2006; Young et al., 2005). The preferential preservation of coccoliths is predominantly due to a difference in calcite crystal size (Adelseck et al., 1973; Hover et al., 2001). First, smaller crystals are more susceptible to dissolution than larger crystals (Hover et al., 2001). Coccolithophores precipitate the coccoliths from an internal vesicle and form two main types of coccoliths: holococcoliths and heterococcoliths (Young et al., 2005). Holococcoliths are made up of $0.1 \mu \mathrm{m}$ euhedral calcite crystals and are therefore very susceptible to dissolution (Bown et al., 2008). However, heterococcoliths are made up of larger, more complexly shaped, single crystals of calcite (Schmidt et al., 2006), which makes them far less susceptible to dissolution (Bown et al., 2008). Holococcoliths are rarely preserved outside of clay-rich sediments (Bown et al., 2008). Dissolution (or etching) of heterococcoliths can range from slight etching (affects delicate structures; creates a serrated edge of coccolith), moderate (delicate structures destroyed; causes coccolith outlines to become irregular) to strong (delicate taxa are rare; coccolith fragments are abundant) etching (Blechschmidt, 1979; Roth and Thierstein, 1972; Roth, 1973, 1983; Su et al., 2000). Recrystallization of coccolith calcite is not common, as holococcoliths mostly dissolve, and the large crystal size of the heterococcoliths makes overgrowth more thermodynamically favorable (Adelseck et al., 1973; Hover et al., 2001). Overgrowth of heterococcoliths can also range from slight (some irregular secondary growth; slight thickening of central coccolith areas) to moderate (common irregular secondary growth; delicate structures overgrown and difficult to recognize) to strong (overgrowth hinders identification) (Adelseck et al., 1973; Roth and Thierstein, 1972; Roth, 1983; Su et al., 2000).

In this data report, foraminifer preservation is assessed using backscattered electron (BSE) SEM on multiple specimens of Cibicidoides mundulus and Globigerinoides sacculifer. Coccolithophore preservation is assessed using BSE and secondary electron (SE)
SEM on the sediment fine fraction $(<63 \mu \mathrm{m})$. The main components of the fine fraction sediment are qualitatively evaluated using energy dispersive spectroscopy (EDS) on an SEM.

\section{Methods and materials}

\section{Sediment processing}

All sediment samples used in this study were selected between 60 and $180 \mathrm{~m}$ core composite depth below seafloor (CCSF-A) along the composite splice at Site U1338 (Wilkens et al., 2013), thereby targeting the late Miocene to early Pliocene based on the shipboard age model (see the "Site U1338" chapter [Expedition 320/321 Scientists, 2010]). Each $20 \mathrm{~cm}^{3}$ sample was freeze-dried and weighed and $5 \mathrm{~cm}^{3}$ was kept as an archive. The remaining $15 \mathrm{~cm}^{3}$ was washed through a $63 \mu \mathrm{m}$ sieve to separate the fine $(<63 \mu \mathrm{m})$ and coarse $(>63 \mu \mathrm{m})$ fractions, both of which were then oven-dried at $45^{\circ} \mathrm{C}$. When the foraminifers were selected, the $>63 \mu \mathrm{m}$ fraction was further dry sieved to isolate specific size fractions.

\section{Scanning electron microscopy}

C. mundulus and Gs. sacculifer were selected from the 250-500 $\mu \mathrm{m}$ and 250-355 $\mu \mathrm{m}$ size fractions, respectively, for SEM to assess the general preservation of these specific benthic and planktonic species throughout the late Miocene to early Pliocene section of the Site U1338 splice (Table T1). Two $<63 \mu \mathrm{m}$ fine fraction samples (c1 and c2) from 76.18 and $105.32 \mathrm{~m}$ CCSF-A were selected to investigate sedimentary composition and coccolith preservation.

Samples were mounted onto sticky carbon tape on a stub and were imaged using the Leo 1455 variable pressure (VP) SEM at the Natural History Museum (NHM; London, United Kingdom). The images were made at low vacuum using backscattered electrons in topography mode (BSE-TOPO) and therefore were not coated. The working distance for all images was set to $15-16 \mathrm{~mm}$, with a spot size of 500 (Leo-specific setting) and an acceleration voltage of $15 \mathrm{kV}$.

As the spatial resolution of the BSE-TOPO approach was insufficient to resolve the smaller scale features of the fine fraction sediments, Sample c2 was coated with platinum (coating thickness $=3 \mathrm{~nm}$ ) and imaged using the JEOL JCM-6000 NeoScope Benchtop SEM in high vacuum mode at Utrecht University (the Netherlands). Images were taken in SE mode at a working distance of $19 \mathrm{~mm}$. The filament and probe currents were set to high, and the acceleration voltage was set at 10 or $15 \mathrm{kV}$, depending on the resolution required. 
To determine the chemical composition of the different sedimentary components, EDS area maps were made of Sample c2. The EDS maps were all made with an acceleration voltage of $15 \mathrm{kV}$ using high filament and probe currents.

\section{Results Foraminifer SEM}

The SEM images show that the benthic foraminifer C. mundulus from Site U1338 generally shows good preservation (Fig. F2). The umbilical and spiral sides of the specimens from 87.13, 129.17, 148.20, and 164.93 m CCSF-A (Fig. F2A, F2E, F2F, F2G, respectively) show only very minor calcite overgrowth, the original pores are still well preserved, and the apertures and individual chambers are well defined. The specimens from 89.53 and $101.38 \mathrm{~m}$ CCSF-A (Fig. F2B, F2C, respectively) show very similar levels of overgrowth as the specimens in Figure F2A, F2E, F2F, and F2G; however, these specimens have possibly experienced very minor dissolution (red arrows in Fig. F2B, F2C) around some of the edges of a few pores on the umbilical side. The umbilical specimens from 115.49 and $176.60 \mathrm{~m}$ CCSF-A (Fig. F2D, F2H umbilical side, respectively) show some evidence of dissolution and large calcite overgrowths that disguise the original pores and chamber structure (red arrows in Fig. F2D, F2H umbilical side). The specimens examined on their spiral sides from both 115.49 and $176.60 \mathrm{~m}$ CCSF-A are relatively well preserved (Fig. F2D, F2H spiral side, respectively).

The planktonic foraminifer SEM images indicate that the specimens are not pristine and that preservation is variable (Fig. F3). All specimens show some levels of recrystallization, ranging from very minor (Fig. F3F, F3K) to high (Fig. F3I, F3J). However, even in the worst recrystallization cases, the original pore structure remains visible, occasionally with the spine bases intact. Blockier, gametogenic calcite is present on the final chamber of all imaged specimens (blue arrows in figure). Specimens from 105.50 and 117.87 $\mathrm{m}$ CCSF-A (Fig. F3F, F3K) show the best preservation. The latter specimen was mechanically broken to expose the wall structure and the inside of the test (Fig. F4). Minor recrystallization of the outer test has occurred in both specimens, and many spine bases remain visible (Fig. F3). The inner wall of the specimen at $117.87 \mathrm{~m}$ CCSF-A only shows minor overgrowth and has retained a smooth surface (Fig. F4). The internal growth structure is still largely retained. However, the microgranular texture of the test wall has recrystallized throughout, as indicated by large calcite crystals visible throughout the wall (Fig. F4). Nonetheless, there is no infilling seen in the speci- men, as the internal wall has remained smooth. Specimens from 63.64, 96.73, 111.70, 125.74, 171.51, and $178.70 \mathrm{~m}$ CCSF-A (Fig. F3A, F3E, F3H, F3M, F3N, F3O, respectively) show more recrystallization, although the spine bases are still frequently visible. The specimens from 74.58, 87.35, 91.23, 110.70 , and $118.87 \mathrm{~m}$ CCSF-A show still more recrystallization, which masks most of the spine bases (Fig. F3B, F3C, F3D, F3G, F3L, respectively). The worst recrystallization was found on specimens from 112.77 and 116.87 m CCSF-A (Fig. F3I, F3J, respectively). Here the spine bases have mostly disappeared and the original pore structure is almost entirely obscured by recrystallization.

\section{Fine fraction SEM}

The BSE SEM images of the Sample c1 and c $2<63 \mu \mathrm{m}$ fractions show the presence of many heterococcolith plates (green circles in Fig. F5) and large fragments of radiolarians and foraminifers (Fig. F5A-F5B). There are also large numbers of whole diatoms present. Higher resolution SE SEM images show that the dominant sedimentary components are coccoliths, coccolith plate and diatom fragments, and small fragments (Fig. F5C-F5D). The small fragments are sometimes distinguishable as very small coccolith or foraminifer fragments (red circles in Fig. F5C-F5D). The fragments are frequently too small to accurately identify their origin but could potentially be fragmented holococcoliths and heterococcoliths. No holococcoliths are identifiable on the higher resolution images, although some of the smaller fragments of calcite may be disintegrated holococcoliths (Fig. F5E). The central structures of the heterococcoliths have not been retained, which suggests slight to moderate dissolution/etching occurred. Most imaged heterococcoliths show minor overgrowths of single calcite cells (red arrows in Fig. F5E, F5G, F5H). However, as a large number of small fragments is present, some of this potential overgrowth could simply be a small fragment attached to the coccolith surface (Fig. F5G). The resolution of the SE SEM micrographs is not sufficiently high to judge whether there is any recrystallization. The original coccolith growth structures are also retained in some of the heterococcoliths (green arrows in Fig. F5F, F5H). However, the absence of holococcoliths and original structures in all heterococcoliths, together with the minor overgrowths and large number of fragments, suggests that the preservation of these samples is moderate, perhaps even moderate to poor.

Qualitative EDS maps (Fig. F6) show that the main chemical components are biogenic calcite $\left(\mathrm{CaCO}_{3}\right.$ represented by the red-colored calcium map) and biogenic silica $\left(\mathrm{SiO}_{2}\right.$ represented by the green-col- 
ored silicon map) (lower section Fig. F6). The lower EDS maps also show some large euhedral to subspherical barite crystals are present $\left(\mathrm{BaSO}_{4}\right.$ represented by the blue-colored barium map), which are most likely marine barite. The red areas of the four EDS overlays show that much of the smaller $(<2 \mu \mathrm{m})$ fragments and particles, which are sometimes distinguishable as coccolith plate fragments, are all calcite.

\section{Calcite preservation- implications for the robustness of geochemical proxies}

Determining the preservation of benthic and planktonic foraminiferal specimens and coccoliths from Site U1338 is important, as it helps to quantify the robustness of the geochemistry on the archives.

The foraminifer BSE-TOPO SEM images show that both the benthic and planktonic foraminifer specimens have undergone some alteration, which was not easily identifiable using RLM. The benthic foraminifers have only slightly been affected (Fig. F2). Out of the eight imaged specimens, six showed good preservation with only very minor overgrowth. The other two specimens showed considerable overgrowth on the umbilical side. Considering Edgar et al. (2013) work on the influence of recrystallization and overgrowth on the $\delta^{18} \mathrm{O}$ and $\delta^{13} \mathrm{C}$ of benthic foraminiferal calcite, stable isotope measurements on benthic foraminifers from this site are probably only minimally affected by diagenesis.

The BSE-TOPO images show that the planktonic foraminifer specimens have undergone far more alteration, with preservation ranging from fair to poor (Figs. F3, F4). Preservation is highly variable, with all specimens showing evidence of some overgrowth and recrystallization. The variability of preservation is interesting, particularly when comparing specimens that are only separated by $\sim 1 \mathrm{~m}$ in depth. Between these specimens (Fig. F3H compared to Fig. F3I and Fig. F3J to F3K), the difference in recrystallization and overgrowth is large. A recent study of planktonic foraminifers in the mid-Miocene section of Site U1338 shows that the preservation of the planktonic foraminifers investigated is generally good (Fox and Wade, 2013). Generally, the specimens have not undergone substantial recrystallization, with the original submicrometer microgranular wall texture remaining intact (Fox and Wade, 2013). The difference in preservation between the foraminifers investigated by Fox and Wade (2013) and the foraminifers investigated in this study is unexpected, as the specimens in Fox and Wade (2013) have experienced greater burial depths (an additional $200 \mathrm{~m}$ or more) than the specimens in this study. This suggests that burial depth was not the main control on diagenetic alteration at this site. Because of the poor to fair preservation of the planktonic foraminifers, stable isotope measurements on this species should be treated cautiously, particularly $\delta^{18} \mathrm{O}$ records, although $\delta^{13} \mathrm{C}$ records do not seem to be much affected by recrystallization (Sexton et al., 2006).

The coccoliths investigated only show moderate or poor to moderate preservation. The SEM study could not resolve sufficiently high spatial resolution to determine whether any of the large or complete heterococcolith fragments had undergone recrystallization, although recrystallization of the heterococcolith calcite is unlikely because of the large crystal size of the individual calcite crystals. Many heterococcoliths show evidence for small amounts of secondary calcite overgrowth (Fig. F5F). In addition, slight to moderate etching must have occurred because none of the heterococcoliths have centrally preserved structures. Overall, both these processes would have reduced the proportion of surface water coccolith calcite present in the sample, which should be taken into account when using this archive for geochemistry.

The high-resolution SEM and EDS images (Figs. F5, F6) show that in addition to the main two components (biogenic $\mathrm{SiO}_{2}$ and $\mathrm{CaCO}_{3}$ ), some marine barite is also present (Fig. F6). The small size $(1-2 \mu \mathrm{m})$ and euhedral to subspherical shape of crystals indicates that the barite is marine barite, rather than hydrothermal or diagenetic barite (Paytan et al., 2002). Marine barite is precipitated in the upper water column during the degradation of organic material, potentially aided by zooplankton and/or bacteria (Griffith and Paytan, 2012). X-ray fluorescence measurements on the Site U1338 core splice indicate that $\mathrm{BaSO}_{4}$ is present throughout the late Miocene and early Pliocene (ranging from 0.5 to $2 \mathrm{wt} \%$ ) (Lyle et al., 2012).

\section{Summary}

The BSE-TOPO SEM images of various benthic and planktonic foraminifer specimens from Site U1338 show that both sets of foraminifers have undergone some alteration. The benthic foraminifers are generally only slightly affected by minor calcite overgrowth. There is also only very minor evidence for dissolution in a couple of the specimens. A quarter of the specimens investigated show a reasonable amount of overgrowth. As diagenetic alteration is not thought to greatly alter the original isotopic composition of the benthic foraminiferal calcite, the 
state of benthic foraminifer preservation is unlikely to be an issue for geochemistry.

The BSE-TOPO SEM images of the planktonic foraminifer specimens show signs of definite alteration. The preservation state ranges from specimens with some overgrowth and internal recrystallization, but which retain original features such as pores, spine pits and internal test-wall growth structure, to specimens where recrystallization and overgrowth disguise many of the original features. Preservation state is also highly variable, with specimens that are $<1 \mathrm{~m}$ apart showing considerably different levels of alteration. Because of the preservation issues, geochemistry on these archives should be interpreted cautiously.

SE and BSE-TOPO SEM images show that coccolith calcite preservation is moderate or moderate to poor. Dissolution has removed all evidence of holococcoliths, and slight to moderate etching has removed the central features of the heterococcolith preservation of the coccolith calcite. A small amount of secondary overgrowth is also visible on many heterococcoliths.

EDS analyses show that the main sedimentary components of the fine fraction sediment is biogenic $\mathrm{CaCO}_{3}$ and $\mathrm{SiO}_{2}$. Marine barite was also found.

\section{Acknowledgments}

The samples used in this study were provided by the Integrated Ocean Drilling Program (IODP) and the IODP Gulf Coast Repository (GCR). The R/V JOIDES Resolution Expedition 320/321 science party members are acknowledged for their effort in collecting the material used in this study. Also thanks to Bridget Wade for her guidance on planktonic foraminiferal taxonomy. This work benefited from the review provided by Andrew Fraass. A.J. Drury was funded by a Janet Watson studentship from Imperial College London, and the SEM work was partially facilitated by a European Consortium for Ocean Research Drilling (ECORD) research grant received by A.J. Drury in 2012.

\section{References}

Adelseck, C.G., Jr., Geehan, G.W., and Roth, P.H., 1973. Experimental evidence for the selective dissolution and overgrowth of calcareous nannofossils during diagenesis. Geol. Soc. Am. Bull., 84(8):2755-2762. doi:10.1130/ 0016-7606(1973)84<2755:EEFTSD>2.0.CO;2

Blechschmidt, G., 1979. Biostratigraphy of calcareous nannofossils: Leg 47B, Deep Sea Drilling Project. In Sibuet, J.C., Ryan, W.B.F., et al., Init. Repts. DSDP, 47 (Pt. 2):
Washington, DC (U.S. Govt. Printing Office), 327-360. doi:10.2973/dsdp.proc.47-2.106.1979

Bown, P.R., and Dunkley Jones, T., 2012. Calcareous nannofossils from the Paleogene equatorial Pacific (IODP Expedition 320 Sites U1331-1334). J. Nannoplankton Res., 32(2):3-51.

Bown, P.R., Dunkley Jones, T., Lees, J.A., Randell, R.D., Mizzi, J.A., Pearson, P.N., Coxall, H.K., Young, J.R., Nicholas, C.J., Karega, A., Singano, J., and Wade, B.S., 2008. A Paleogene calcareous microfossil KonservatLagerstätte from the Kilwa Group of coastal Tanzania. Geol. Soc. Am. Bull., 120(1-2):3-12. doi:10.1130/ B26261.1

Edgar, K.M., Pälike, H., and Wilson, P.A., 2013. Testing the impact of diagenesis on the $\delta^{18} \mathrm{O}$ and $\delta^{13} \mathrm{C}$ of benthic foraminiferal calcite from a sediment burial depth transect in the equatorial Pacific. Paleoceanography, 28(3):468-480. doi:10.1002/palo.20045

Expedition 320/321 Scientists, 2010. Site U1338. In Pälike, H., Lyle, M., Nishi, H., Raffi, I., Gamage, K., Klaus, A., and the Expedition 320/321 Scientists, Proc. IODP, 320/ 321: Tokyo (Integrated Ocean Drilling Program Management International, Inc.). doi:10.2204/

iodp.proc.320321.110.2010

Fox, L.R., and Wade, B.S., 2013. Systematic taxonomy of early-middle Miocene planktonic foraminifera from the equatorial Pacific Ocean: Integrated Ocean Drilling Program, Site U1338. J. Foraminiferal Res., 43(4):374-405. doi:10.2113/gsjfr.43.4.374

Griffith, E.M., and Paytan, A., 2012. Barite in the oceanoccurrence, geochemistry and paleoceanographic applications. Sedimentology, 59(6):1817-1835. doi:10.1111/ j.1365-3091.2012.01327.x

Hover, V.C., Walter, L.M., and Peacor, D.R., 2001. Early marine diagenesis of biogenic aragonite and Mg-calcite: new constraints from high-resolution STEM and AEM analyses of modern platform carbonates. Chem. Geol., 175(3-4):221248. doi:10.1016/S0009-2541(00)00326-0

Lyle, M., Barron, J., Bralower, T.J., Huber, M., Olivarez Lyle, A., Ravelo, A.C., Rea, D.K., and Wilson, P.A., 2008. Pacific Ocean and Cenozoic evolution of climate. Rev. Geophys., 46(2). doi:10.1029/2005RG000190

Lyle, M., Olivarez Lyle, A., Gorgas, T., Holbourn, A., Westerhold, T., Hathorne, E., Kimoto, K., and Yamamoto, S., 2012. Data report: raw and normalized elemental data along the Site U1338 splice from X-ray fluorescence scanning. In Pälike, H., Lyle, M., Nishi, H., Raffi, I., Gamage, K., Klaus, A., and the Expedition 320/ 321 Scientists, Proc. IODP, 320/321: Tokyo (Integrated Ocean Drilling Program Management International, Inc.). doi:10.2204/iodp.proc.320321.203.2012

Lyle, M., Pälike, H., Nishi, H., Raffi, I., Gamage, K., Klaus, A., and the IODP Expeditions 320/321 Scientific Party, 2010. The Pacific Equatorial Age Transect, IODP Expeditions 320 and 321: building a 50-million-year-long environmental record of the equatorial Pacific Ocean. Sci. Drill., 9:4-15. doi:10.2204/iodp.sd.9.01.2010

Pälike, H., Nishi, H., Lyle, M., Raffi, I., Gamage, K., Klaus, A., and the Expedition 320/321 Scientists, 2010. Expedition 320/321 summary. In Pälike, H., Lyle, M., Nishi, H., 
Raffi, I., Gamage, K., Klaus, A., and the Expedition 320/ 321 Scientists, Proc. IODP, 320/321: Tokyo (Integrated Ocean Drilling Program Management International, Inc.). doi:10.2204/iodp.proc.320321.101.2010

Pälike, H., Lyle, M.W., Nishi, H., Raffi, I., Ridgwell, A., Gamage, K., Klaus, A., Acton, G., Anderson, L., Backman, J., Baldauf, J., Beltran, C., Bohaty, S.M., Bown, P., Busch, W., Channell, J.E.T., Chun, C.O.J., Delaney, M., Dewangan, P., Dunkley Jones, T., Edgar, K.M., Evans, H., Fitch, P., Foster, G.L., Gussone, N., Hasegawa, H., Hathorne, E.C., Hayashi, H., Herrle, J.O., Holbourn, A., Hovan, S., Hyeong, K., Iijima, K., Ito, T., Kamikuri, S., Kimoto, K., Kuroda, J., Leon-Rodriguez, L., Malinverno, A., Moore, T.C., Jr., Murphy, B.H., Murphy, D.P., Nakamura, H., Ogane, K., Ohneiser, C., Richter, C., Robinson, R., Rohling, E.J., Romero, O., Sawada, K., Scher, H., Schneider, L., Sluijs, A., Takata, H., Tian, J., Tsujimoto, A., Wade, B.S., Westerhold, T., Wilkens, R., Williams, T., Wilson, P.A., Yamamoto, Y., Yamamoto, S., Yamazaki, T., and Zeebe, R.E., 2012. A Cenozoic record of the equatorial Pacific carbonate compensation depth. Nature, 488(7413):609-614. doi:10.1038/nature11360

Paytan, A., Mearon, S., Cobb, K., and Kastner, M., 2002. Origin of marine barite deposits: $\mathrm{Sr}$ and $\mathrm{S}$ isotope characterization. Geology, 30(8):747-750. doi:10.1130/00917613(2002)030<0747:OOMBDS>2.0.CO;2

Pearson, P.N., and Burgess, C.E., 2008. Foraminifer test preservation and diagenesis: comparison of high latitude Eocene sites. In Austin, W.E.N., and James, R.H. (Eds.), Biogeochemical Controls on Palaeoceanographic Environmental Proxies. Geol. Soc. Spec. Publ., 303(1):5972. doi:10.1144/SP303.5

Pearson, P.N., Ditchfield, P.W., Singano, J., HarcourtBrown, K.G., Nicholas, C.J., Olsson, R.K., Shackleton, N.J., and Hall, M.A., 2001. Warm tropical sea surface temperatures in the Late Cretaceous and Eocene epochs. Nature, 413(6855):481-487. doi:10.1038/35097000

Roth, P.H., 1973. Calcareous nannofossils_Leg 17, Deep Sea Drilling Project. In Winterer, E.L., Ewing, J.I., et al., Init. Repts. DSDP, 17: Washington, DC (U.S. Govt. Printing Office), 695-795. doi:10.2973/ dsdp.proc.17.123.1973

Roth, P.H., 1983. Jurassic and Lower Cretaceous calcareous nannofossils in the western North Atlantic (Site 534): biostratigraphy, preservation, and some observations on biogeography and paleoceanography. In Sheridan, R.E., Gradstein, F.M., et al., Init. Repts. DSDP, 76: Washington, DC (U.S. Govt. Printing Office), 587-621. doi:10.2973/ dsdp.proc.76.125.1983

Roth, P.H., and Thierstein, H., 1972. Calcareous nannoplankton: Leg 14 of the Deep Sea Drilling Project. In Hayes, D.E., Pimm, A.C., et al., Init. Repts. DSDP, 14: Washington, DC (U.S. Govt. Printing Office), 421-485. doi:10.2973/dsdp.proc.14.114.1972
Ryan, W.B.F., Carbotte, S.M., Coplan, J.O., O'Hara, S., Melkonian, A., Arko, R., Weissel, R.A., Ferrini, V., Goodwillie, A., Nitsche, F., Bonczkowski, J., and Zemsky, R., 2009. Global multi-resolution topography synthesis. Geochem., Geophys., Geosyst., 10(3):Q03014. doi:10.1029/2008GC002332

Schmidt, D.N., Lazarus, D., Young, J.R., and Kucera, M., 2006. Biogeography and evolution of body size in marine plankton. Earth-Sci. Rev., 78(3-4):239-266. doi:10.1016/j.earscirev.2006.05.004

Sexton, P.F., and Wilson, P.A., 2009. Preservation of benthic foraminifera and reliability of deep-sea temperature records: the importance of sedimentation rates, lithology, and the need to examine test wall structure. Paleoceanography, 24(2):PA2208. doi:10.1029/ 2008PA001650

Sexton, P.F., Wilson, P.A., and Pearson, P.N., 2006. Microstructural and geochemical perspectives on planktic foraminiferal preservation: "glassy" versus "frosty." Geochem., Geophys., Geosyst., 7(12):Q12P19. doi:10.1029/2006GC001291

Su, X., Baumann, K.-H., and Thiede, J., 2000. Calcareous nannofossils from Leg 168: biochronology and diagenesis. In Fisher, A., Davis, E.E., and Escutia, C. (Eds.), Proc. ODP, Sci. Results, 168: College Station, TX (Ocean Drilling Program), 39-49. doi:10.2973/

odp.proc.sr.168.015.2000

Wade, B.S., Pearson, P.N., Berggren, W.A., and Pälike, H., 2011. Review and revision of Cenozoic tropical planktonic foraminiferal biostratigraphy and calibration to the geomagnetic polarity and astronomical time scale. Earth-Sci. Rev., 104(1-3):111-142. doi:10.1016/j.earscirev.2010.09.003

Wilkens, R.H., Dickens, G.R., Tian, J., Backman, J., and the Expedition 320/321 Scientists, 2013. Data report: revised composite depth scales for Sites U1336, U1337, and U1338. In Pälike, H., Lyle, M., Nishi, H., Raffi, I., Gamage, K., Klaus, A., and the Expedition 320/321 Scientists, Proc. IODP, 320/321: Tokyo (Integrated Ocean Drilling Program Management International, Inc.). doi:10.2204/iodp.proc.320321.209.2013

Young, J.R., Geisen, M., and Probert, I., 2005. A review of selected aspects of coccolithophore biology with implications for paleobiodiversity estimation. Micropaleontology, 51(4):267-288. doi:10.2113/gsmicropal.51.4.267

Initial receipt: 2 May 2014

Acceptance: 23 July 2014

Publication: 15 October 2014

MS 320321-218 
Figure F1. Location map of sites drilled during Expedition 320/321. Site U1338, which was the primary focus of this study, is located furthest to east. The backtracked location of Site U1338 (from Pälike et al., 2012) is also shown, with the sites location between 3.5 and 8.0 Ma highlighted in red. The map was made using GeoMapApp (Ryan et al., 2009).

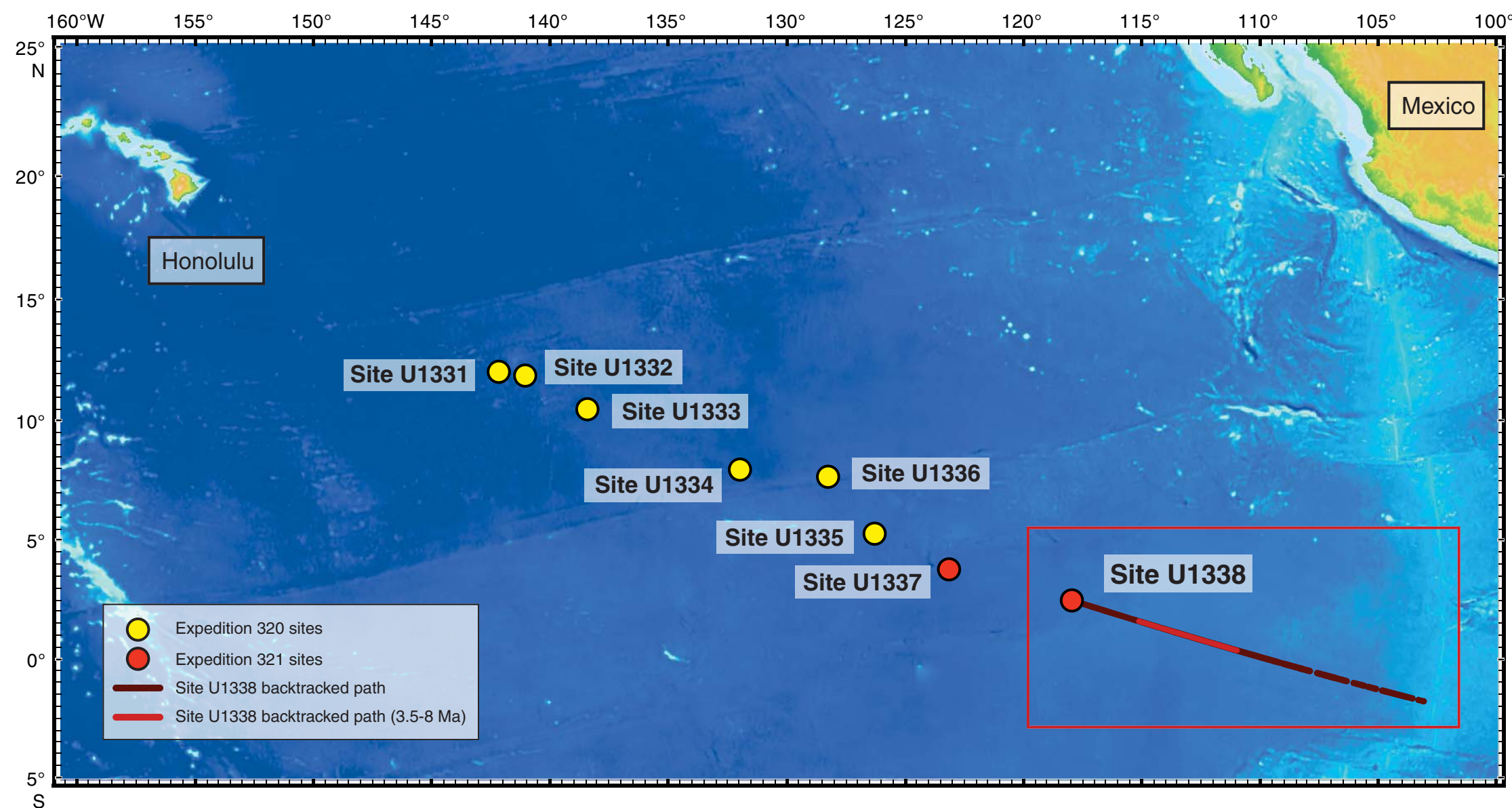


Figure F2. BSE-TOPO SEM images of 14 benthic Cibicidoides mundulus from 8 samples selected between 87.13 and $176.60 \mathrm{~m}$ CCSF-A on the Site U1338 splice. A, E, F, G. Specimens generally show only minor calcite overgrowth, and the pore structures are still very well preserved. B, C. Specimens generally show similar preservation levels shown in A and E to G, although there is some evidence of minor dissolution around some of the pores (red arrows). D, H. Specimens show greater degrees of diagenetic alteration than the other specimens; umbilical specimen shown in $\mathrm{H}$. Both specimens show evidence of dissolution, as well as large calcite overgrowths (red arrows). The specimens imaged from their spiral side in D and $\mathrm{H}$ do not show much overgrowth, or any signs of dissolution.

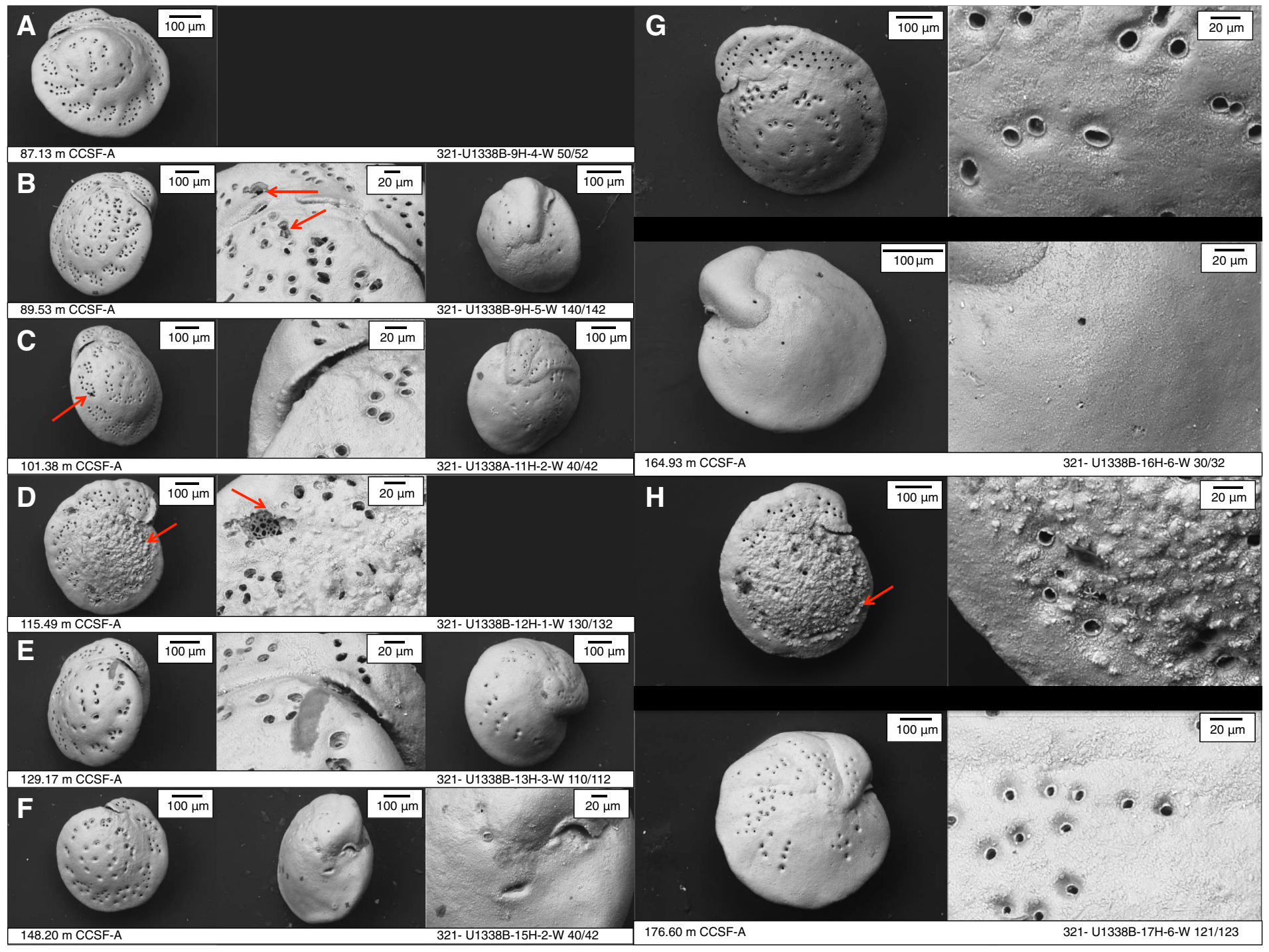


Figure F3. BSE-TOPO SEM images of 16 mixed-layer planktonic Globigerinoides sacculifer from 15 samples selected between 87.13 and $176.60 \mathrm{~m}$ CCSF-A on the Site U1338 splice. Generally, the SEM images show that none of the specimens are pristine, and that the preservation is variable. F, K. Specimens show the best preservation, with only minor recrystallization and overgrowth on the outer test, and many pores and spine bases still well defined. A, E, H, M, N, O. Specimens show evidence of greater recrystallization than specimens F and K, with more widespread recrystallization and overgrowth. Despite this, many pores and spine bases still remain visible. B, C, D, G, L. Specimens show a greater degree of alteration, as most of the spine bases are no longer visible, and the pores have been considerable narrowed by the calcite overgrowth. I, J. The worst recrystallization is found on these specimens, where the spine bases are almost entirely overgrown, and the original pore structure is almost completely obscured by recrystallization and overgrowth. Gametogenic calcite is indicated with blue arrows.
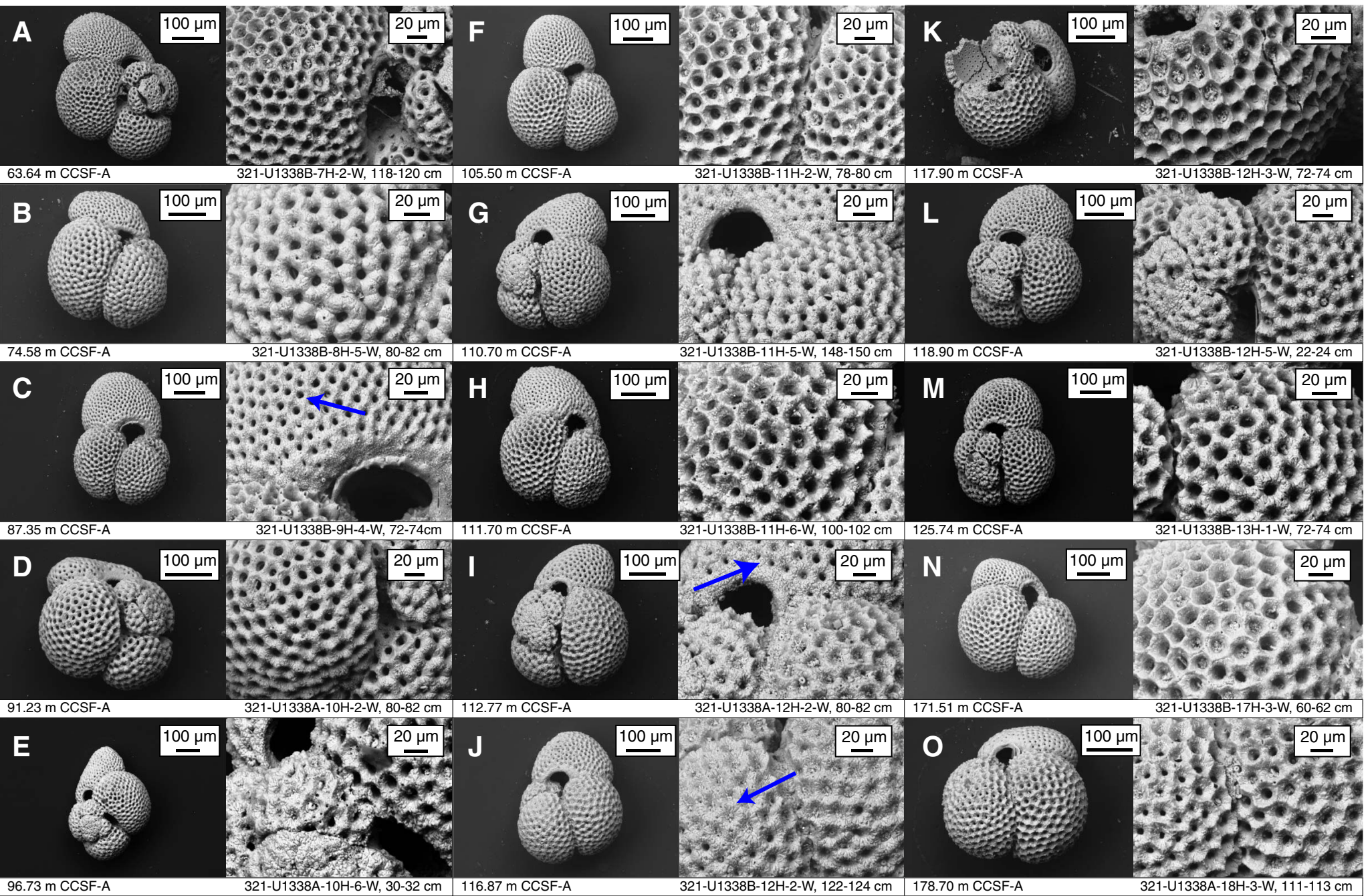
Figure F4. More detailed BSE-TOPO SEM images of the mechanically broken mixed-layer planktonic Globigerinoides sacculifer from $117.90 \mathrm{~m}$ CCSF-A on the Site U1338 splice (cf. Fig. F3K). This specimen was one of the better-preserved Gs. sacculifer imaged. There is only minor overgrowth on the outer test wall, and the original pores remain clear, with many of the spine bases still visible. The inner test wall only shows minor overgrowth, and has generally retained the smooth texture, which is characteristic for the internal wall of many planktonic species (Pearson and Burgess, 2008). The test-wall cross section shows that the internal growth structure is still largely retained. However, the microgranular texture that would have originally made up the test wall has been recrystallized and replaced with large calcite crystals.

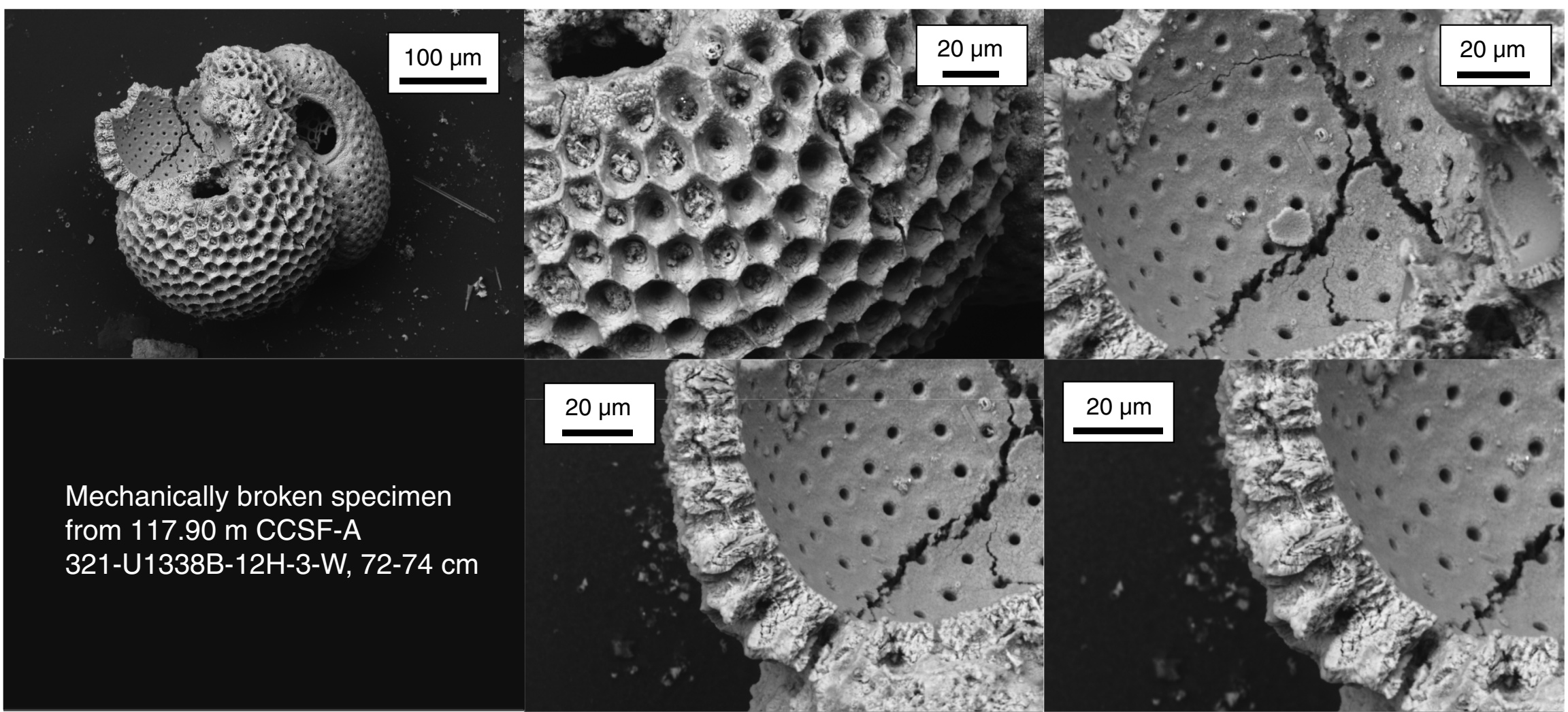


Figure F5. The BSE SEM images of the fine fraction $(<63 \mu \mathrm{m})$ Samples $(\mathrm{A}) \mathrm{c} 1$ and $(\mathbf{B}) \mathrm{c} 2$ show the presence of many heterococcolith plates, whole diatoms, and large fragments of radiolarians and foraminifers. C, D. Highresolution SE SEM images of Sample c2 show the presence of large numbers of coccoliths (green circles). The images also show the presence of small fragments that are partially made up of foraminiferal and coccolith fragments (red circles). E, F, G, H. High-resolution SE SEM images of Sample c2 show that coccoliths have experienced slight to minor etching, although there is considerable fragmentation. Some original microstructures are retained (green arrows), but there is some evidence of calcite overgrowths (red arrows).
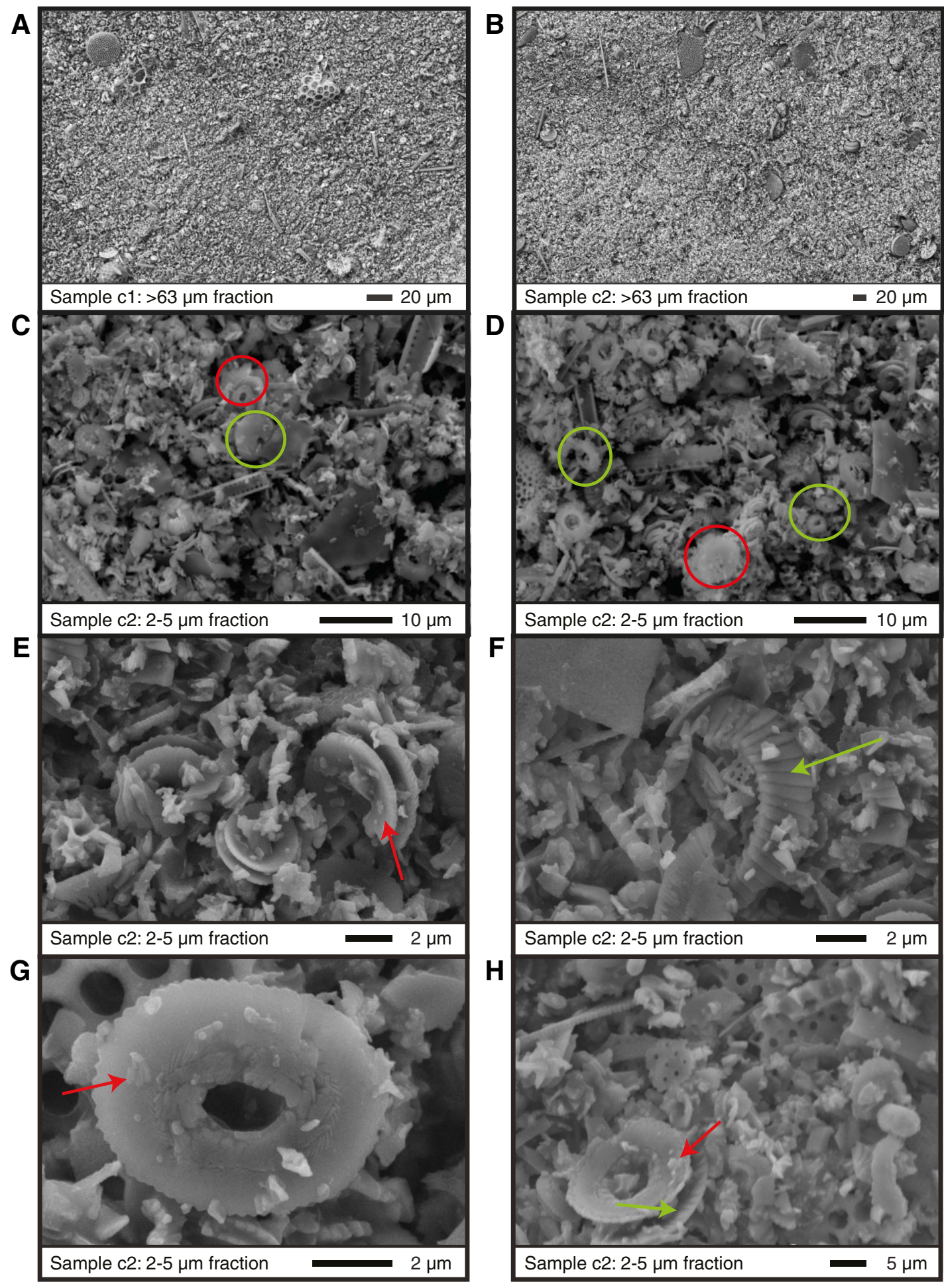
Figure F6. Overview of representative areas that were elementally mapped using energy dispersive spectroscopy (EDS) on Sample c2. In the upper section, the individual area image and barium, calcium, and silicon EDS maps are shown. For a different area, an overlay of $\mathrm{Ba}, \mathrm{Ca}$, and $\mathrm{Si}$ over the image is shown below. These EDS maps show that the main two components are biogenic $\mathrm{SiO}_{2}$ (green areas) and $\mathrm{CaCO}_{3}$ (red areas), although there is also some marine barite present (blue areas) in this area.
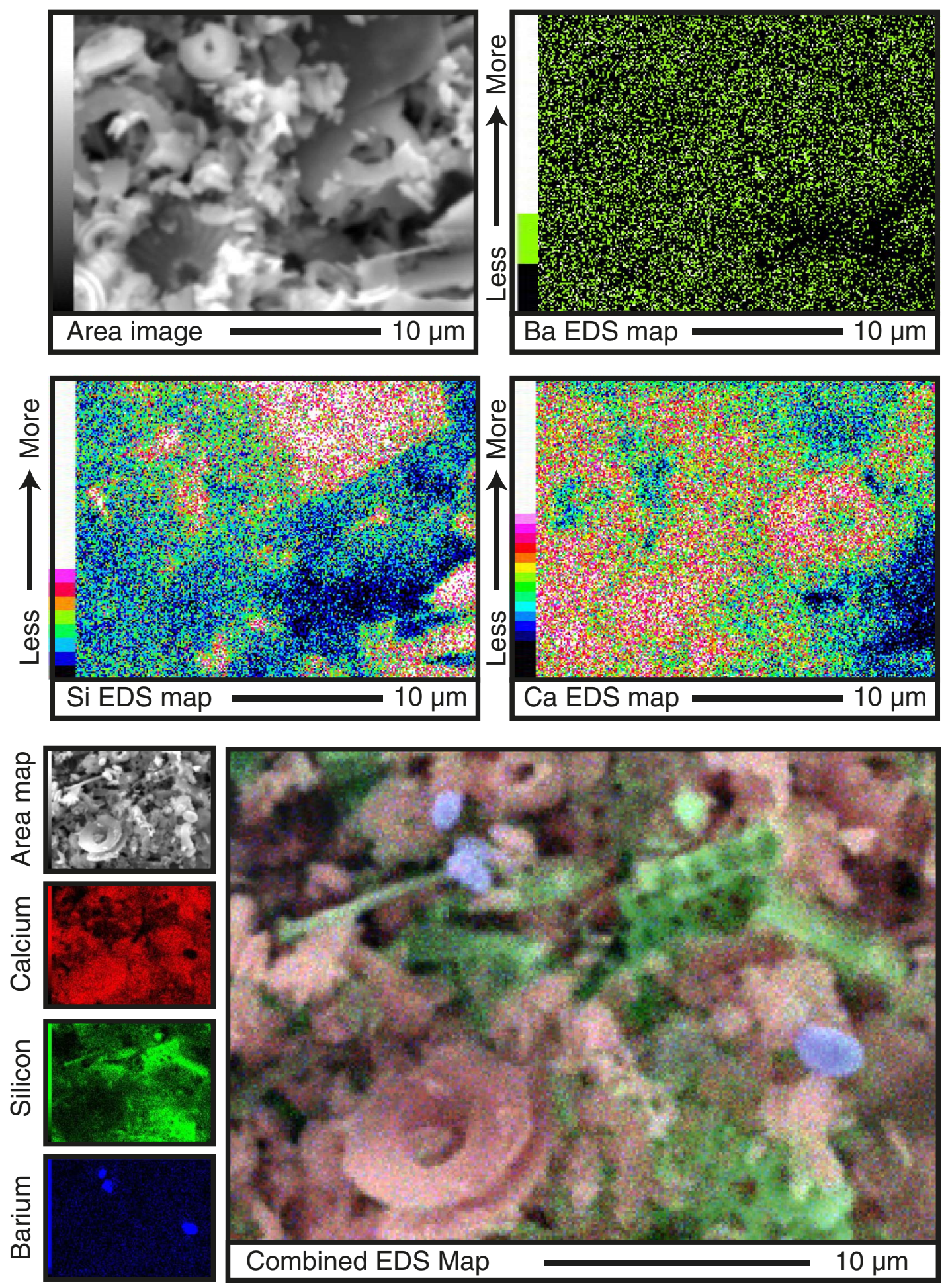
Table T1. Overview of the samples investigated in this study, and the respective focus of the scanning electron microscope (SEM) analyses.

\begin{tabular}{|c|c|c|c|c|c|}
\hline $\begin{array}{l}\text { Hole, core, section, interval } \\
(\mathrm{cm})\end{array}$ & Label & $\begin{array}{l}\text { Depth } \\
\text { CCSF-A } \\
(\mathrm{m})^{\star}\end{array}$ & $\begin{array}{c}\text { Planktonic } \\
\text { foraminifer } \\
\text { zone }^{\dagger}\end{array}$ & Figure & SEM analysis of \\
\hline \multicolumn{6}{|l|}{ 321- } \\
\hline U1338B-7H-2W, 118-120 & & 63.64 & PL1 & $\mathrm{F} 3 \mathrm{~A}$ & Globigerinoides sacculifer \\
\hline U1338B-8H-5W, 80-82 & & 74.58 & PL1 & F3B & Globigerinoides sacculifer \\
\hline U1338B-9H-4W, 72-74 & & 87.35 & PL1 & $\mathrm{F} 3 \mathrm{~B}$ & Globigerinoides sacculifer \\
\hline U1338A-10H-2W, 80-82 & & 91.23 & PL1 & F3D & Globigerinoides sacculifer \\
\hline U1338A-10H-6W, 30-32 & & 96.73 & M14 & $\mathrm{F} 3 \mathrm{E}$ & Globigerinoides sacculifer \\
\hline U1338B-11H-2W, 78-80 & & 105.50 & M14 & F3F & Globigerinoides sacculifer \\
\hline U1338B-11H-5W, 148-150 & & 110.70 & M14 & F3G & Globigerinoides sacculifer \\
\hline U1338B-11H-6W, 100-102 & & 111.70 & M14 & $\mathrm{F} 3 \mathrm{H}$ & Globigerinoides sacculifer \\
\hline U1338A-12H-2W, 80-82 & & 112.77 & M14 & $\mathrm{F} 3 \mathrm{I}$ & Globigerinoides sacculifer \\
\hline U1338B-12H-2W, 122-124 & & 116.87 & M14 & F3ן & Globigerinoides sacculifer \\
\hline U1338B-12-3W, 72-74 & & 117.90 & M14 & $\mathrm{F} 3 \mathrm{~K}$ and $\mathrm{F} 4$ & Globigerinoides sacculifer \\
\hline U1338B-12H-5W, 22-24 & & 118.90 & M14 & $\mathrm{F} 3 \mathrm{~L}$ & Globigerinoides sacculifer \\
\hline U1338B-13H-1W, 72-74 & & 125.74 & M14 & $\mathrm{F} 3 \mathrm{M}$ & Globigerinoides sacculifer \\
\hline U1338B-17H-3W, 60-62 & & 171.51 & M13b & $\mathrm{F} 3 \mathrm{~N}$ & Globigerinoides sacculifer \\
\hline U1338A-18H-3W, 111-113 & & 178.70 & M13b & $\mathrm{F} 3 \mathrm{O}$ & Globigerinoides sacculifer \\
\hline U1338B-9H-4W, 50-52 & & 87.13 & PL1 & $\mathrm{F} 2 \mathrm{~A}$ & Cibicidoides mundulus \\
\hline U1338B-9H-5W, 140-142 & & 89.53 & PL1 & $\mathrm{F} 2 \mathrm{~B}$ & Cibicidoides mundulus \\
\hline U1338A-11H-2W, 40-42 & & 101.38 & M14 & $\mathrm{F} 2 \mathrm{C}$ & Cibicidoides mundulus \\
\hline U1338B-12H-1W, 130-132 & & 115.49 & M14 & F2D & Cibicidoides mundulus \\
\hline U1338B-13H-3W, 110-112 & & 129.17 & M13b & $\mathrm{F} 2 \mathrm{E}$ & Cibicidoides mundulus \\
\hline U1338B-15H-2W, 40-42 & & 148.20 & M13b & $\mathrm{F} 2 \mathrm{~F}$ & Cibicidoides mundulus \\
\hline U1338B-16H-6W, 30-32 & & 164.93 & M13b & F2G & Cibicidoides mundulus \\
\hline U1338B-17H-6W, 121-123 & & 176.60 & M13b & $\mathrm{F} 2 \mathrm{H}$ & Cibicidoides mundulus \\
\hline U1338B-8H-4W, 50-52 & Sample c1 & 76.18 & PL1 & $\mathrm{F} 5 \mathrm{~A}, \mathrm{~F} 5 \mathrm{C}, \mathrm{F} 5 \mathrm{E}$, and $\mathrm{F} 5 \mathrm{C}$ & Fine fraction sediment $(<63 \mu \mathrm{m})$ \\
\hline U1338B-11H-2W, 60-62 & Sample c2 & 105.32 & M14 & $\mathrm{F} 5 \mathrm{~B}, \mathrm{~F} 5 \mathrm{D}, \mathrm{F} 5 \mathrm{~F}, \mathrm{~F} 5 \mathrm{H}$, and F6 & Fine fraction sediment $(<63 \mu \mathrm{m})$ \\
\hline
\end{tabular}

* = from Wilkens et al., 2013, $\dagger=$ from Wade et al., 2011. 